\title{
Metasychis varicollaris sp. nov., and report of Metasychis gotoi (Maldanidae, Annelida) from the China Seas
}

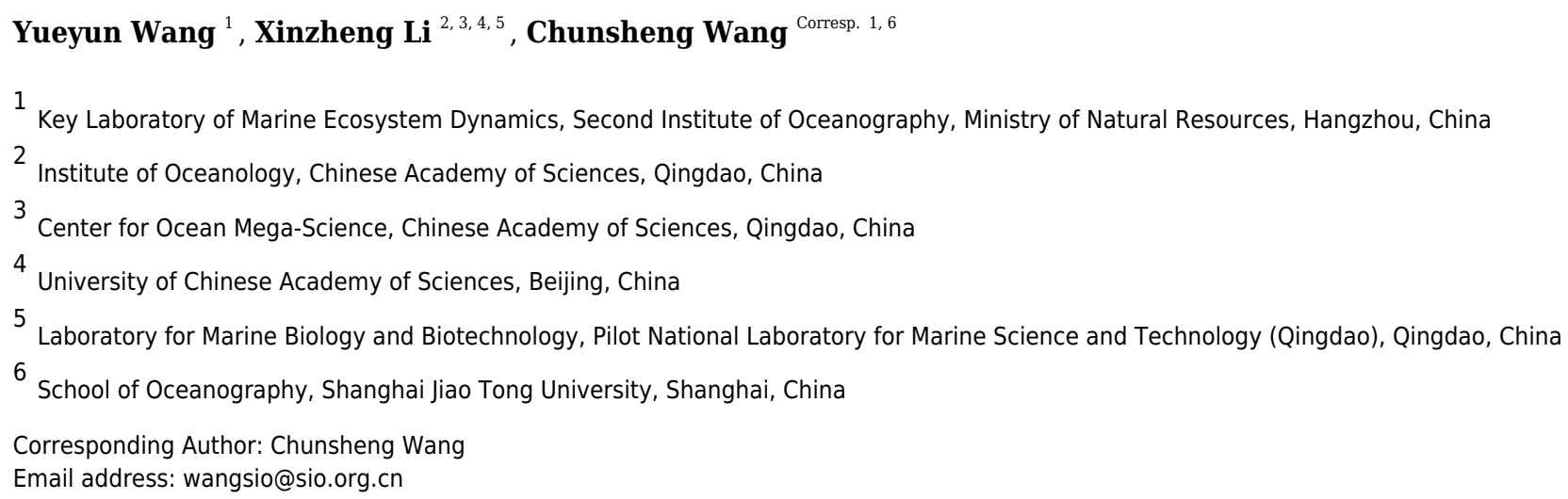

Polychaete species are widely distributed throughout Indo-Pacific and European waters. We collected Metasychis specimens from the China Seas to report on Metasychis varicollaris sp. n. and Metasychis gotoi (Izuka, 1922) in greater detail. Geographic analysis of the potential distribution areas of $M$. gotoi indicates that it may be found in most coastal areas of China. The newly discovered species, M. varicollaris and M. gotoi, have an overlapping distribution in the northern South China Sea. Metasychis varicollaris $\mathrm{sp} . \mathrm{n}$. is characterized by a crenulated cephalic rim, complete collar on chaetiger 1, a packetshaped anal funnel, and a spirally-fringed notochaetae with spiral pectinate bands imbricated over the main shaft. Our study provides a taxonomic key to all species of Metasychis. 


\section{Metasychis varicollaris sp. nov., and report of}

\section{Metasychis gotoi (Maldanidae, Annelida) from the}

\section{China Seas}

4

5 Yueyun Wang ${ }^{1}$, Xinzheng $\mathrm{Li}^{2,3,4,5}$, Chunsheng Wang ${ }^{1,6 *}$

6 of Natural Resources, Hangzhou, Zhejiang, China

${ }^{4}$ University of Chinese Academy of Sciences, Beijing, China Science and Technology (Qingdao), Qingdao, Shandong, China

Corresponding Author:

Chunsheng Wang ${ }^{1}$

Baochubei Road 36, Hangzhou, Zhejiang, 310012, China

Email address: wangsio@sio.org.cn

\section{Abstract} taxonomic key to all species of Metasychis.

\section{Introduction}

${ }^{1}$ Key Laboratory of Marine Ecosystem Dynamics, Second Institute of Oceanography, Ministry

2 Institute of Oceanology, Chinese Academy of Sciences, Qingdao, Shandong, China

${ }^{3}$ Center for Ocean Mega-Science, Chinese Academy of Sciences, Qingdao, Shandong, China

${ }^{5}$ Laboratory for Marine Biology and Biotechnology, Pilot National Laboratory for Marine

${ }^{6}$ School of Oceanography, Shanghai Jiao Tong University, Shanghai, China

Polychaete species are widely distributed throughout Indo-Pacific and European waters. We collected Metasychis specimens from the China Seas to report on Metasychis varicollaris sp. $\mathrm{n}$. and Metasychis gotoi (Izuka, 1922) in greater detail. Geographic analysis of the potential distribution areas of $M$. goto i indicates that it may be found in most coastal areas of China. The newly discovered species, $M$. varicollaris and $M$. gotoi, have an overlapping distribution in the northern South China Sea. Metasychis varicollaris sp. n. is characterized by a crenulated cephalic rim, complete collar on chaetiger 1, a packet-shaped anal funnel, and a spirally-fringed notochaetae with spiral pectinate bands imbricated over the main shaft. Our study provides a 
33 Maldanids, with their segmental bodies, are an easily recognizable polychaete family.

34 Individuals have elongated segments from the median to the posterior regions of the body, with 35 the parapodia resembling slender bamboo-shoots at one end (Fauchald, 1977). Maldanids are 36 found in hard or soft substrates from the intertidal region to the deep sea (Paterson et al., 2009; 37 De Assis \& Christoffersen, 2011). Malmgren erected the family Maldanidae in 1867. Arwidsson

38

39

40

41

42

61 (1906) subsequently divided the family into five subfamilies: Euclymeninae, Lumbriclymeninae, Maldaninae, Nicomachinae, and Rhodininae. Three additional subfamilies have since been proposed: Clymenurinae (Imajima \& Shiraki, 1982a), Bogueinae (Wolf, 1983), and Notoproctinae (Detinova, 1985). De Assis and Christoffersen (2011) proposed the phylogenetic relationships of Maldanidae subgroups based morphological data, however, the subfamilies Clymenurinae and Bogueinae were not supported by the character-based phylogenetic tree estimated using maximum parsimony. Therefore, Clymenurinae was included with Euclymeninae, and Bogueinae with Rhodininae. Kobayashia et al. (2018) reconstructed the molecular phylogeny and confirmed the monophyly of the subfamilies Rhodininae, Maldaninae, Lumbriclymeninae, and Nicomachinae. The subfamily Euclymeninae was shown as monophyletic (De Assis and Christoffersen, 2011), but was recovered as paraphyletic and Nicomachinae was clustered within it (Kobayashi et al., 2018).

The Maldaninae genus Metasychis, was erected by Light (1991) to include four species: $M$. collariceps (Augener, 1906), M. disparidentatus (Moore, 1904), M. fimbriatus (Treadwell, 1934), and M. gotoi (Izuka, 1902). The members of Metasychis are distinguished by their welldeveloped cephalic rim with crenulations or cirri, J- or U- shaped nuchal grooves, chaetiger 1 with reduced or complete collar, notochaetae on the middle body with spirally fringed distal ends, and a funnel-like pocket anal plate. Only one Metasychis species, Metasychis gotoi, was recorded from the China Seas (Liu, 2008; Yang \& Sun, 1988) which are located in the western North Pacific and include the Bohai Sea, Yellow Sea, East China Sea and South China Sea. We examined the Maldaninae specimens deposited in the Marine Biological Museum of the Chinese Academy of Sciences (MBMCAS) and describe a new species of Metasychis from the northern South China Sea where the species are known to overlap.

\section{Materials \& Methods}

We examined all of the Maldaninae specimens deposited in the Marine Biological Museum of the Chinese Academy of Sciences (MBMCAS) in the Institute of Oceanology (IOCAS) that were collected during the National Comprehensive Oceanography Survey (NCOS, 1958-1960) and the Sino-Vietnam Joint Comprehensive Oceanographic Survey of Beibu Gulf (1959-1961). The 
67 specimens were preserved in a solution of $75 \%$ ethanol. The sampling sites are shown in Figure 681.

69 The potential geographic distributions of Metasychis gotoi were predicted using the MaxEnt 70 program (Steven et al., 2019) with dismo packages (Hijmans et al., 2017) in an R environment. 71 Ten environmental variables (mean of chlorophyll, dissolved oxygen, iron, nitrate, phosphate, 72 phytoplankton, primary productivity, salinity, silicate, and temperature at present benthic mean 73 depth) were downloaded from Bio-ORACLE (Tyberghein et al., 2012; Assis et al., 2018) and

74115 presence localities were used in the analysis. Twenty-five percent of the locations were 75 selected randomly for modeling and were evaluated using the evaluate function in dismo 76 package.

77 We made morphological observations with a Zeiss Stemi 2000-C stereo microscope and 78 compound microscope. Line drawings were made using a UGEE electronic drawing tablet in 79 Adobe Photoshop. We rinsed the samples for viewing with a scanning electron microscope 80 (SEM) with distilled waters for 12 hours to dissolve mineral crystals. We then ran the samples 81 through a series of ethanol concentrations and stored them in absolute alcohol until observations were made.

\section{$83 \quad$ Nomenclatural acts}

84 The electronic version of this article in Portable Document Format (PDF) will represent a 85 published work according to the International Commission on Zoological Nomenclature (ICZN), 86 and hence the new names contained in the electronic version are effectively published under that 87 Code from the electronic edition alone. This published work and the nomenclatural acts it 88 contains have been registered in ZooBank, the online registration system for the ICZN. The ZooBank LSIDs (Life Science Identifiers) can be resolved and the associated information viewed through any standard web browser by appending the LSID to the prefix http://zoobank.org/. The LSID for this publication is: [urn:lsid:zoobank.org:pub:A018F8D0-F9A6-4D64-B2064FFB39160032]. The online version of this work is archived and available from the following digital repositories: PeerJ, PubMed Central, and CLOCKSS.

\section{Results}

96 Family Maldanidae Malmgren, 1867

97 Subfamily Maldaninae Malmgren, 1867

98 Genus Metasychis Light, 1991

99 Metasychis Light, 1991: 133-146; Wang \& Li, 2016: 13.

100 Type species: Metasychis disparidentatus (Moore, 1904) 
101 Diagnosis (after Light 1991, different feature highlighted in italicized). Body with 19 chaetigers, 102 without neurochaetae on the first chaetigers. Lateral cephalic rim with crenulations or digitate 103 cirri, fusing with expanded prostomial palpode or setting off from it by furrows, connecting to J104 or U-shaped nuchal groove or not connecting to nuchal groove. Collar on chaetiger 1 complete, 105 or reduced to a thick ventral roll of tissue. Notochaetae including spirally-fringed fimbriae. One 106 pygidial achaetigerous segments or none. No anal valve. Pygidium well developed, forming a 107 deep, posterior, funnel-like pocket, with a pair of deep lateral notches. Dorsal lobe of the 108 pygidium with or without cirri.

109 Remarks. In Light's (1991) description, the Metasychis species usually has type B notochaetae, 110 in which the fimbriae are more delicate and expanded away from the shaft (sometimes type A) in 111 which the fimbriae are spinose and closely imbricated over the main shaft. The notochaetae 112 examined here in M. varicollaris sp. n. and M. gotoi are closer to type A notochaetae in Light 113 (1991).

114 Several specimens with a distinct collar were observed in the Metasychis material in the Marine 115 Biological Museum of the Chinese Academy of Sciences and they should belong to a new 116 species. They are described below.

117

118 Metasychis varicollaris sp. $\mathbf{n}$.

119 (Figs. 2-3)

120 Material examined. Holotype. MBM 012597, South China Sea, st. $6052,21.5^{\circ} \mathrm{N}, 114^{\circ} \mathrm{E}, 54.5 \mathrm{~m}$ 121 depth, 9 Apr. 1959. Complete specimen, length ca. $67 \mathrm{~mm}$, width ca. $2.2 \mathrm{~mm}$ at chaetiger 1 , with 122 muddy tube encompassment. Paratypes. MBM 012647, South China Sea, st. $6045,21.75^{\circ} \mathrm{N}$, $123114.5^{\circ} \mathrm{E}, 61 \mathrm{~m}$ depth, 20 Mar. 1959. Anterior fragment with 10 chaetigers. Chaetigers $11-12$ 124 were used in SEM examination. MBM 012658, South China Sea, st. $6045,21.75^{\circ} \mathrm{N}, 114.5^{\circ} \mathrm{E}$, 12559.6 m, muddy sediment, 8 Apr. 1960. MBM 012676, South China Sea, st. $6116,21^{\circ} \mathrm{N}, 111.5^{\circ} \mathrm{E}$, $12641 \mathrm{~m}$ depth, muddy sediment, 12 Apr. 1959. Other specimens examined. MBM 012576, South 127 China Sea, st. $6051,21.75^{\circ} \mathrm{N}, 114^{\circ} \mathrm{E}, 44 \mathrm{~m}$, muddy sediment, 9 Dec. 1959. MBM 012674, South 128 China Sea, st. $6131,20^{\circ} \mathrm{N}, 111.25^{\circ} \mathrm{E}, 50 \mathrm{~m}$, muddy sediment, 6 Apr. 1960. MBM 012645, South 129 China Sea, st. $6131,20^{\circ} \mathrm{N}, 111.25^{\circ} \mathrm{E}, 44 \mathrm{~m}, 29$ Oct. 1959.

130 Description. Body cylindrical, with 19 chaetigers, and a funnel-shaped pygidium (Fig. 2A-D; 131 Fig. 3E, F). Body color in alcohol yellow. The first 6-7 parapodial tori with glandular pads (Fig.

132 3A). Anterior end obliquely truncate, with an elliptical cephalic plate (Fig. 2B, E; Fig. 3D). 133 Cephalic rim divided into three parts by a pair of deep lateral notches. Triangular to rounded 134 crenulations on cephalic rim well-developed; 4-6 crenulations on lateral part, 12-16 on posterior 135 part (Fig. 2B; Fig. 3D). Prostomial palpode broadly rounded. Eyes absent. Nuchal groove 
136 curved, slightly J-shaped (Fig. 2B, E), with many small curly cilia (Fig. 2F). Cephalic keel 137 remarkable, high and long, wider posteriorly (Fig. 2B, E).

138 First three chaetigers relatively short, about 1-2 times as long as wide, biannulate in lateral 139 view (Fig. 2A; Fig. 3A). Prominent complete collar on chaetiger 1. Dorsal part well-developed, 140 longer than ventral part, extending forward (Fig. 2A; Figs. 3B, C). Mid-body, and posterior 141 chaetigers typically with inflated neuropodial tori. Neurochaetae present from chaetiger 2, 142 typically rostrate uncini similar on all chaetigers without significant variation between the first 143 three uncini from subsequent uncini, arranged in a row on neuropodial tori (Figs. 2G, H).

144 Capitium of uncinus with 5-6 transverse arcs of small teeth. First arc with about 12 small teeth 145 larger than on other arcs. A tuft of bristles under main fang. Anterior chaetigers with two kinds 146 simple capillary notochaetae (Fig. 2I): limbate capillary with narrow wing on one side (Fig. 2L) 147 and common capillary without similar structures (Fig. 2M). Middle and posterior chaetigers with 148 long spirally-fringed notochaetae and companion geniculate notochaetae (Figs. 2J, K, N). Long 149 spirally-fringed notochaetae with two spirally pectinate bands imbricated over the main shaft. 150 Pre-pygidial achaetigerous segment absent. Anal mound well-developed (Fig. 2C; Figs.3E, F). 151 Anal pore without anal valve. Anal funnel elliptical in end view. Deep lateral notches separating anal funnel into dorsal and ventral lobes. Dorsal lobe expanded, disc-shaped, without marginal cirri observed. Ventral lobe forming shallow posterior pocket, with a widen midventral notch. Etymology. "vario", Latin: different, various; "collare”, Latin: collar, neck. The specific name varicollaris referres to the collar shape of this species different from that of congeneric members. Distribution. Northern South China Sea.

Remarks. Metasychis varicollaris sp. n. is morphologically similar to M. gotoi, especially in body size and cephalic plate. However, the new species has a fully developed collar in chaetiger 1, as opposed to a ventral collar in M. gotoi. Metasychis collariceps (Augener, 1906) and M. fimbriatus (Treadwell, 1934) also have a complete collar on chaetiger 1 . The new species can be distinguished from the two species by the shape of collar and cephalic rim. Collar is laterally notched in $M$. collariceps but is full in the new species. The margin of the posterior cephalic rim is complete in $M$. fimbriatus but is crenulated in the new species.

164

Metasychis gotoi (Izuka, 1902)

166 (Fig. 4)

167 Maldane gotoi Izuka, 1902, p.109, Pl. 28, figs. 1-8

168 Asychis gotoi (Izuka, 1902) - Imajima and Shiraki, 1982b, p.75, fig. 36a-1; Yang and Sun, 1988, 169 pp.264-265, fig. $125 \mathrm{~F}-\mathrm{K}$

170 Maldane coronata Moore, 1903, p. 483-485, Pl. 28, figs. 94-96

171 Metasychis gotoi (Izuka, 1902)-Light, 1991, fig.1L-M 
172 Material examined. MBM 006305-006307; 006310-006312; 006317; 006320; 006347;

173 006355; 006412; 007966; 007967; 008113; 008119; 008138; 012498; 012518; 012564-012566;

174 012569; 012571; 012573-012574; 012577-012580; 012582; 012586; 012588-012591;

175 012593;012603-012607; 012611; 012615-012619; 012621-012626; 012628; 012630; 012633;

176 012636; 012640-012643; 012646; 012648; 012650-012652; 012654-012655; 012657; 012660;

177 012664-012665; 012668-012670; 012675; 012677; 012679; 012681; 012685-012687; 012708;

178 012715; 012730; 201449-201455; 201457-201461; 201463; 201466; 201475-201492.

179 Speciemens were collected from the Bohai Sea, Yellow Sea, East China Sea and northern South

180 China Sea. Location information provided in supplemental files 3.

181 Diagnosis. Cylindrical body with nineteen chaetigers. Chaetiger 1 with a short ventral collar

182 (Fig. 4B, C). First four chaetigers biannulate dorsally, and usually with epidermal glands.

183 Following 5-6 chaetigers only with ventral epidermal glands (Fig. 4D).

184 Cephalic plate elliptical (Fig. 4A). Prostomial palpode broadly rounded, mushroom-shaped.

185 Cephalic rim developed, divided into three parts by two lateral notches. Lateral cephalic rim with 186 5-7 digitate cirri (Figs. 4A-C). Posterior rim with irregular crenulations, sometimes with several

187

188

189

190

191

192

193

194

195

196

197

198

199

200

201

202

203

204

205

206

207 small cirri. Cephalic keel short and broad. Nuchal groove curved, slightly J-shaped, extending outwards and forwards, forming a faint notch separating lateral cephalic rims from prostomial palpode.

Anal plate well developed, divided into a flaring dorsal lobe and a deep funnel-shaped ventral lobe (Figs. 4E, F). Margin of dorsal lobe usually with six slender cirri.

Notochaetae arranged in two rows. Anterior chaetigers with simple capillary notochaetae including stout notochaetae and short companion chaetae (Figs. 4G, J). Middle and posterior chaetigers with geniculate companion chaetae and spirally fringed notochaetae, spinose spiral bands closely imbricated over main shaft (Figs. 4H, I, N, O). Chaetiger 1 without neurochaetae. Neurochaetae from chaetiger 2, rostrate uncini with several transversal rows of small teeth on main fang (Figs. 4K-M).

Tube encrusted with mud.

Distribution. Metasychis gotoi is widely distributed in the Indo-Pacific Ocean (Fauvel, 1932; Yang \& Sun, 1988; Liu, 2008) and may be introduced in the Mediterranean Sea (Zenetos et al., 2010). Predicted potential distribution shows that M. gotoi may occur in most coastal areas of China (Fig. 1).

Remarks. Metasychis gotoi is distinguishable from other species of Metasychis by its developed crenulated cephalic rim, ventral collar on chaetiger 1 and anal cirri. This combination of characteristics is most similar to M. disparidentatus. However, there is no cirrus on the anal plate of M. disparidentatus.

Peer] reviewing PDF | (2020:06:50223:3:1:NEW 26 Nov 2020) 


\section{Discussion}

209 Light (1991) revised the subfamily Maldaninae and listed four Metasychis species (M.

210 collariceps; M. disparidentatus; M. fimbriatus; M. gotoi). Wang and Li (2016) proposed a key to

211 distinguish the Maldaninae genera. Based on those definitions, Asychis has no collar on chaetiger

212 1. Three genera of Maldaninae, Chirimia (Light, 1991), Metasychis (Light, 1991), and Sabaco

213 (Kinberg, 1867) have a collar on chaetiger 1; Sabaco is characterized by crescentic nuchal

214 grooves and a smooth cephalic rim. Chirimia and Metasychis have a mushroom-shaped palpod,

215 and J or U-shaped nuchal grooves. Chirimia is distinguishable from Metasychis by the presence

216 of an anal valve. Additionally, the pygidium of Metasychis is more developed than that of

217 Chirimia. Metasychis collariceps was first described as a member of genus Maldane (Augener,

218 1906). Hartman (1938) transferred it to the genus Asychis. Light (1991) revised the subfamily

219 Maldaninae and transferred it to the genus Metasychis. Metasychis collariceps has a complete

220 collar on chaetiger 1 and a dentate lateral cephalic rim, based on its original description.

221 Additional information is needed to confirm its taxonomic status. The species identification has

222 been temporarily assigned based on the information that was available at the time. Metasychis

223 disparidentatus is type species of this genus designated by Light (1991). It has a collar limited to

224 the ventral side of chaetiger 1, J-shaped nuchal grooves, and a well-developed pygidium.

225 Metasychis fimbriatus was first described as a member of genus Maldanella by Treadwell (1934).

226 Hartman (1956) transferred it to the genus Asychis. Later, Light (1991) transferred it to the genus

227 Metasychis. It has a complete collar on chaetiger 1 and a well-developed pygidium with cirri on

228 its dorsal lobe based on original description (Treadwell, 1934).

\section{Conclusions}

230 Maldaninae is a poorly known subfamily of Maldanidae because of inadequate descriptions of 231 early-described species, requirements for complete specimens for complete identification.

232 Correct taxonomy is critical for biodiversity mapping and environmental surveillance monitoring.

233 The present study reported the most comprehensive survey of Metasyshis species from coastal

234 waters of China, detailed information of taxonomy and distribution. The description of new

235 Metasyshis species from southern China contributes to better understand its diversity worldwide.

236 To date, members of Metasychis are reported to have limited geographical distribution except $M$.

237 gotoi. Metasychis collariceps distributed in Caribbean Sea, M. disparidentatus from western

238 Canada south to Southern California and Japan, M. fimbriatus is distributed in Puerto Rico. The

239 five species may be distinguished by the following key:

240 Key to species of Metasychis Light, 1991

241 1. Fully developed collar on chaetiger 1 .2 
242 Collar limited to ventral side of chaetiger 1 .4

243 2. Collar entire without lateral notches 3

244 Collar with lateral notches M. collariceps (Augener, 1906)

245 3. Posterior part of cephalic rim crenulated M. varicollaris sp. nov.

246 Posterior part of cephalic rim entire M. fimbriatus (Treadwell, 1934)

247 248 249 250

251

252 253 254 255 256

257

258

259

260

261

262

263

264

265

266

267

268

269

270

271

272

273

274

4. Cephalic rim with faint crenulations; anal plate without cirri..M. disparidentatus (Moore, 1904) Lateral lobes of cephalic rim usually with digitate cirri; dorsal lobe of the anal plate with slender cirri M. gotoi (Izuka, 1902)

\section{Acknowledgements}

The authors with to thank VLIZ Library for providing important references as well as Dr. De Assis and two anonymous reviewers for giving us valuable comments and suggestions on the manuscript. We also thank the managers of the Marine Biological Museum of the Chinese Academy of Sciences for their help in sorting the material.

\section{References}

Arwidsson I. 1906. Studien über die Skandinavischen und Arktischen Maldaniden nebst zusammenstellung der übrigen bisher bekannten Arten dieser Familie. Zoologische Jahrbcher 9(Suppl.): 1-308.

Assis J, Tyberghein L, Bosh S, Verbruggen H, Serrão E, De Clerck O. 2018. Bio-ORACLE v2.0: Extending marine data layers for bioclimatic modelling. Global Ecology and Biogeography 27(3): 277-284. https://doi.org/10.1111/geb.12693

Augener H. 1906. Reports on the results of dredging, under the supervision of Alexander Agassiz, in the Gulf of Mexico and the Caribbean Sea, and on the east coast of the United States, 1877 to 1880, by the U.S. Coast Survey Steamer Blake, Lieut. Commander C.D. Sigsbee, U.S.N., and Commander J.R. Bartlett, U.S.N. commanding. 42. Westindische Polychaeten. Bulletin of the Museum of Comparative Zoology 43: 91-196.

De Assis JE, Christoffersen ML. 2011. Phylogenetic relationships within Maldanidae (Capitellida: Annelida), based on morphological characters. Systematics and Biodiversity 9: 41-55. doi: $10.1080 / 14772000.2011 .604358$

Detinova NN. 1985. Taxonomy, composition and distribution of polychaetes of subfamily Lumbriclymeninae (Maldanidae). Issledovaniya Fauny Morei 34:25-29. 
275 Fauchald K.1977. The polychaete worms, definitions and keys to the orders, families and genera. Natural

276

277

278

279

280

281

282

283

284

285

286

287

288

289

290

291

292

293

294

295

296

297

298

299

300

301

302

303

304

305

306

307

308

309 History Museum of Los Angeles County, Science Series 28: 1-188.

Hartman O. 1938. Annotated list of the types of polychaetous annelids in the Museum of Comparative Zoology. Bulletin of the Museum of Comparative Zoology at Harvard College 85(1): 3-31

Hartman O. 1956. Polychaetous annelids erected by Treadwell, 1891 to 1948, together with a brief chronology. Bulletin of the American Museum of Natural History 109(2): 239-310.

Imajima M, Shiraki Y. 1982a. Maldanidae (Annelida: Polychaeta) from Japan. (Part 1). Bulletin of the National Science Museum, series A (Zoology) 8(1): 7-46.

Imajima M, Shiraki Y .1982b. Maldanidae (Annelida: Polychaeta) from Japan. (Part 2). Bulletin of the National Science Museum, series A (Zoology) 8(2): 47-88.

Izuka A. 1902. On two new species of the family Maldanidae from the Sagami Bay. Annotationes zoologicae japonenses 4(4): 109-114.

Kobayashi G, Goto R, Takano T, Kojima S. 2018. Molecular phylogeny of Maldanidae (Annelida): Multiple losses of tube-capping plates and evolutionary shifts in habitat depth. Molecular Phylogenetics and Evolution 127:332-344.

Light WHJ .1991. Systematic revision of the genera of the Polychaeta subfamily Maldaninae Arwidsson. Ophelia Supplement 5: 133-146.

Liu R. 2008. Checklist of Marine Biota of China Seas (in Chinese). Beijing: Science Press, 446.

Malmgren AJ.1867. Annulata Polychaeta Spetsbergiae, Gröenlandiae, Islandiae et Scandinaviae hactenus cognita. Ex Officina Frenckelliana, Helsingforslae. doi: 10.5962/bhl.title.13358

Moore JP. 1903. Polychaeta from the coastal slope of Japan and from Kamchatka and Bering Sea. Proceedings of the Academy of Natural Sciences of Philadelphia 55: 401-490.

Moore JP. 1904. New Polychaeta from California. Proceedings of the Academy of Natural Sciences of Philadelphia 56:484-503.

Paterson GL, Glover AG, Froján CB, Whitaker A, Budaeva N, Chimonides J, Doner S. 2009. A census of abyssal polychaetes. Deep Sea Research Part II: Topical Studies in Oceanography 56(19): 17391746. doi: 10.1016/j.dsr2.2009.05.018

Hijmans RJ, Phillips S, Leathwick J, Elith J. 2017. dismo: Species Distribution Modeling. R package version 1.1-4. https://CRAN.R-project.org/package=dismo

Steven J. Phillips, Miroslav Dudík, Robert E. Schapire. [Internet] Maxent software for modeling species niches and distributions (Version 3.4.1). Available at http://biodiversityinformatics.amnh.org/open_source/maxent/ (Accessed on 16 April 2019)

Treadwell AL. 1934. Reports on the collections obtained by the first Johnson-Smithsonian DeepSea Expedition to the Puerto Rican deep. New polychaetous annelids. Smithsonian Miscellaneous Collections 91(8):1-9. 
310 Tyberghein L, Verbruggen H, Pauly K, Troupin C, Mineur F, De Clerck O. 2012. Bio-ORACLE: A

311 global environmental dataset for marine species distribution modelling. Global Ecology and

312 Biogeography 21: 272-281.

313 Wolf PS. 1983. A revision of the Bogueidae Hartman and Fauchald, 1971, and its reduction to Bogueinae, 314 a subfamily of Maldanidae (Polychaeta). Proceedings of the Biological Society of Washington 96(2):

$315 \quad 238-249$.

316 Wang Y, Li X. 2016. A new Maldane species and a new Maldaninae genus and species (Maldanidae, 317 Annelida) from coastal waters of China. ZooKeys 603: 1-16. doi: 10.3897/zookeys.603.9125

318 Yang D, Sun R. 1988. Polychaetous Annelids Commonly Seen from China Coastal Waters (in Chinese). 319 Beijing: China Agriculture Press: 257-267.

320 Zenetos A, Verlaque M, Gofas S, Çinar ME, Garcia RE, Azzurro E, Bilecenoglu M, Froglia C, Siokou I, 321 Bianchi CN, Morri C, Sfriso A, San MG, Giangrande A, Katag An T, Ballesteros E, Ramos EA, 322 Mastrototaro F, Ocana O, Zingone A, Cantone G, Gambi MC, and Streftaris N. 2010. Alien species 323 in the Mediterranean Sea by 2010. A contribution to the application of European Union's Marine 324 Strategy Framework Directive (MSFD). Part I. Spatial distribution. Mediterranean Marine Science $325 \quad 11: 381-493$. 
Figure 1

Sampling sites of Metasychis varicollaris sp. $\mathrm{n} .(\mathrm{x})$ and Metasychis gotoi (+)

Colors indicating predicted probability of suitable conditions for M. gotoi. 


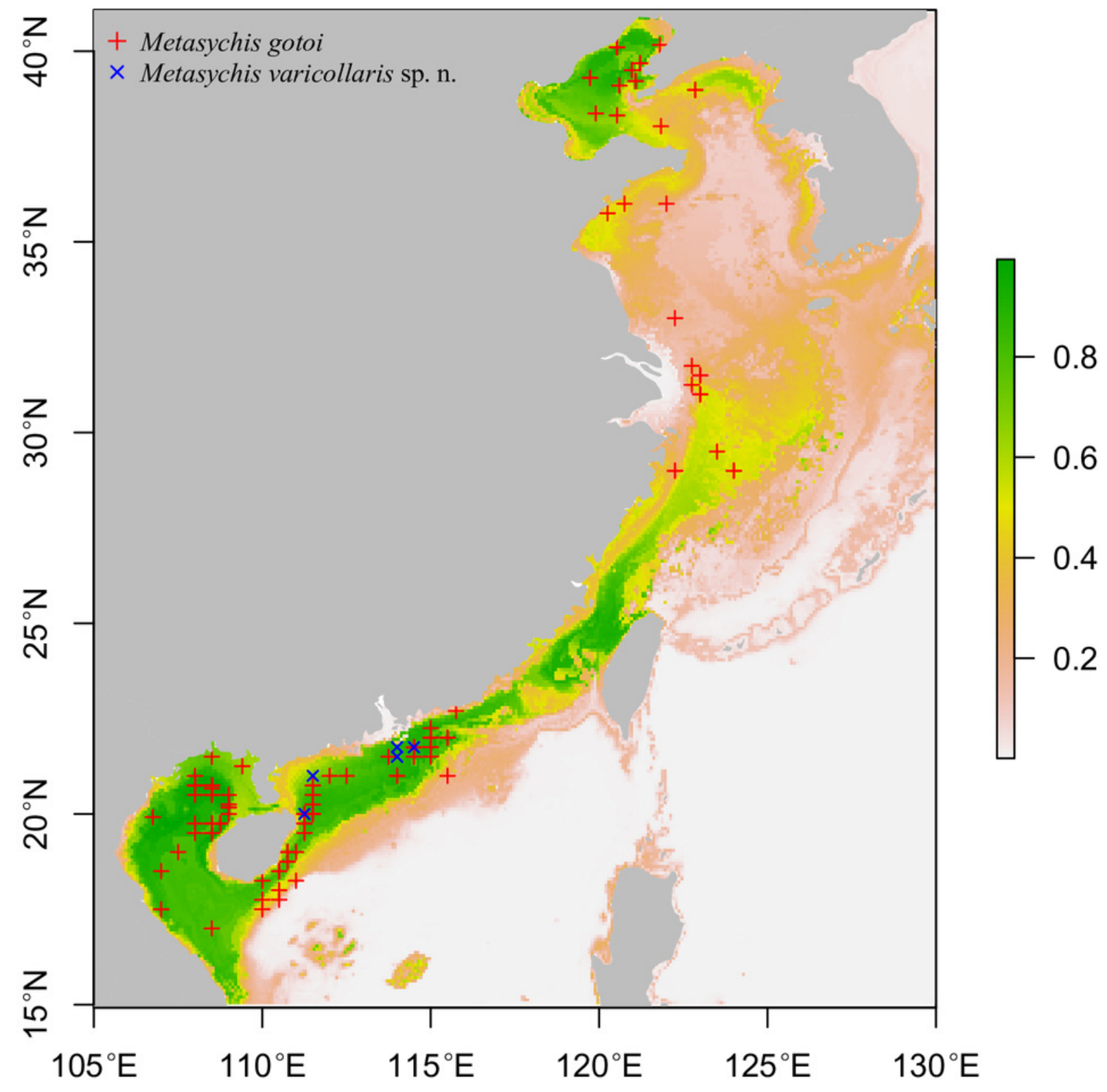


Figure 2

Metasychis varicollaris sp. $\mathrm{n}$.

(A) Anterior region in lateral view. (B) Cephalic plate in dorsal view. (C) Pygidium in lateral

view. (D) Pygidium in ventral view. (E) Cephalic plate in dorsal view. (F) Nuchal groove. (G) Neurochaetae in chaetiger 6 . (H) Neurochaetae in chaetiger 11. (I) Notochaetae in chaetiger 5. (J) Notochaetae in chaetiger 11. (K) Spinose part of notochatae. (L) Limbate capillary. (M) Common capillary. (N) Geniculate notochaetae. Scale bars: $1.0 \mathrm{~mm}(\mathrm{~A}-\mathrm{E}), 10 \mu \mathrm{m}(\mathrm{F}-\mathrm{H}, \mathrm{K})$, $100 \mu \mathrm{m}(\mathrm{I}-\mathrm{J})$. 

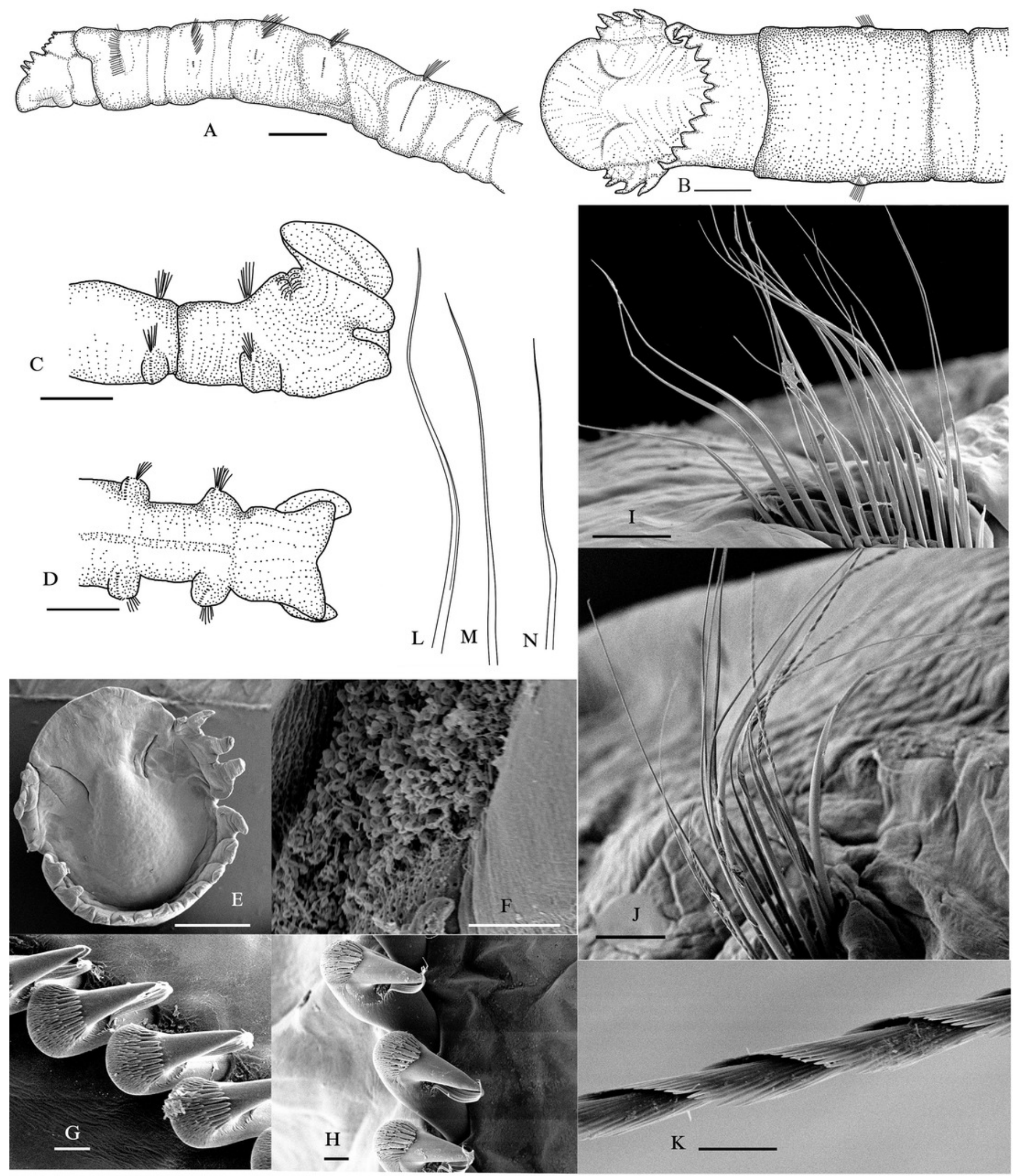

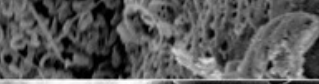
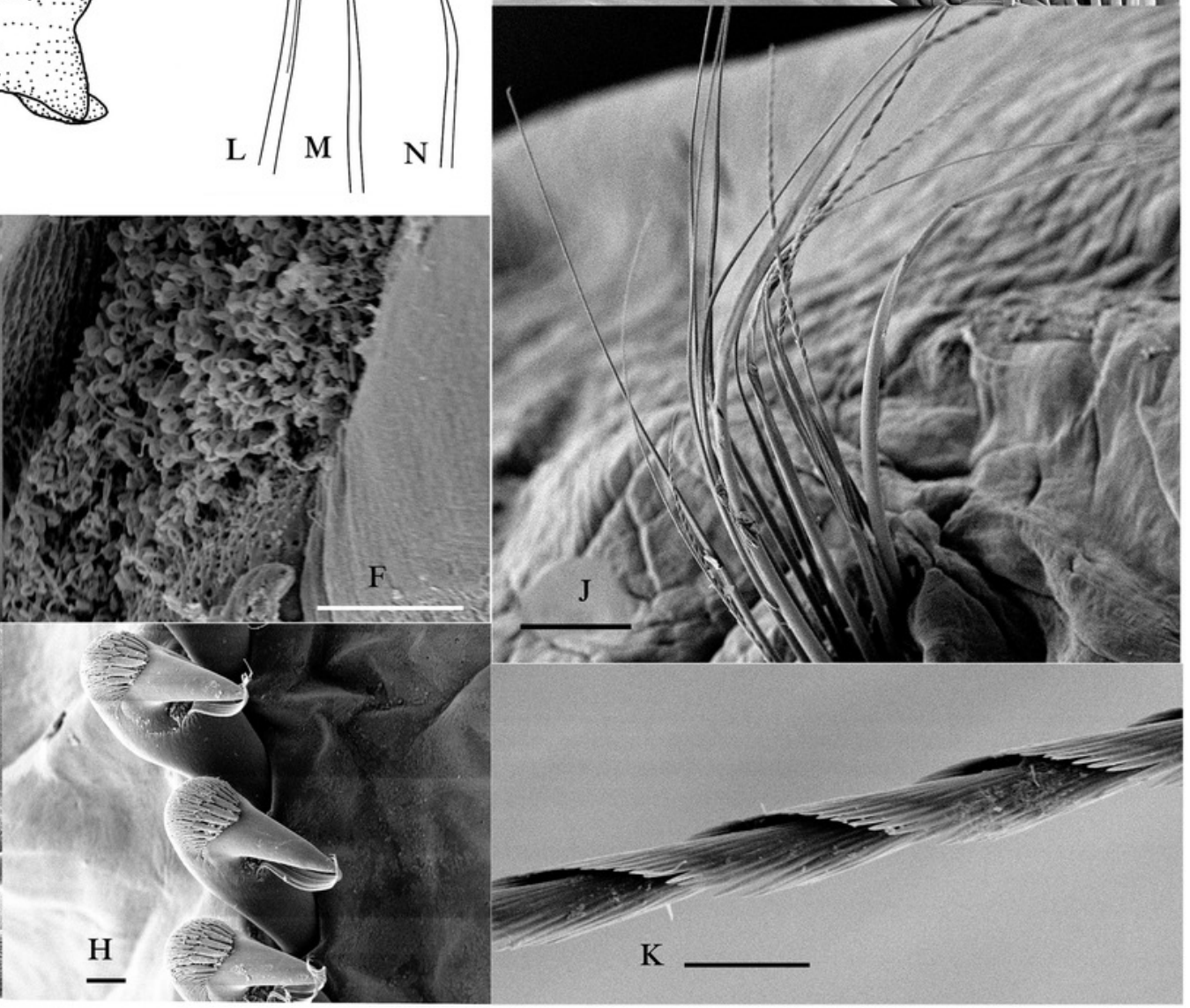


\section{Figure 3}

Metasychis varicollaris sp. $\mathrm{n}$.

(A) Anterior region in lateral view. (B-C) Head in lateral view. (D) Head in dorsal view. (E) Pygidium in ventral view. (F) Pygidium in dorsal view. Scale bars: $1.0 \mathrm{~mm}$.

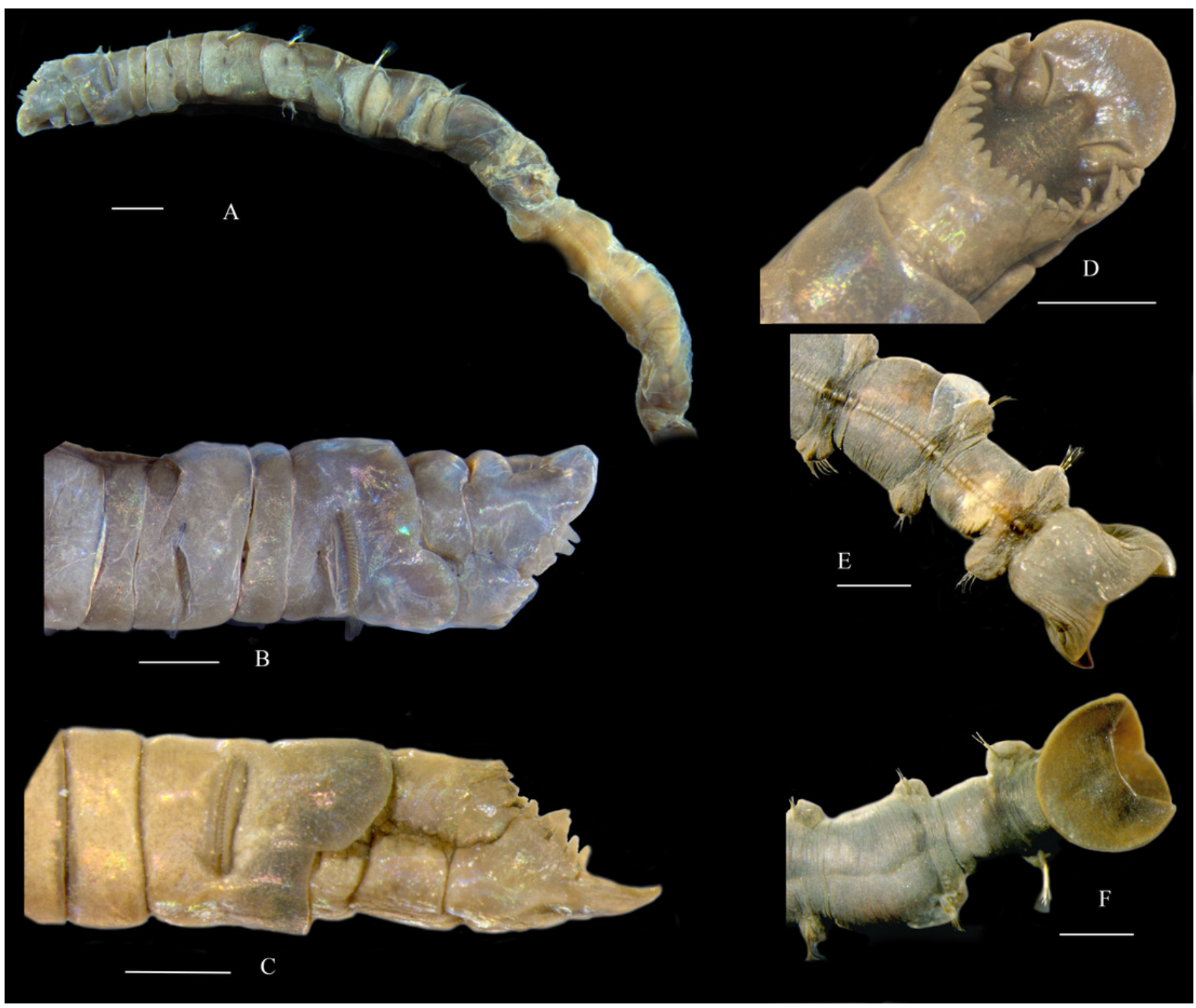




\section{Figure 4}

Metasychis gotoi (Izuka, 1902)

(A) Head region in dorsal view. (B-C) Head region in lateral and ventral views, respectively.

(D) Anterior segments in lateral view. (E-F) Pygidium in ventral and lateral view. (G)

Capillary notochaeta and short slender companion notochaetae on anterior segments. (H-I) Limbate notochaeta with spirally fringed tip and geniculate notochaeta on middle segments. (J-O) SEM images of chaetae. (J) Notochaetae on chaetiger 2. (K-L) Neurochaetae on chaetiger 2. (M) Uncini on chaetiger 11 in apex view. (N) Spirally fringed notochaetae. (0)

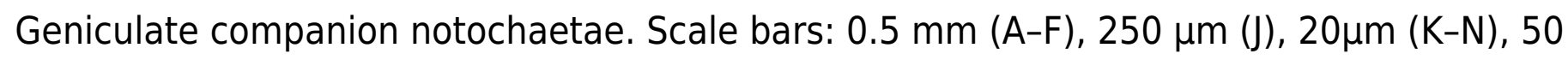
$\mu \mathrm{m}(0)$. 

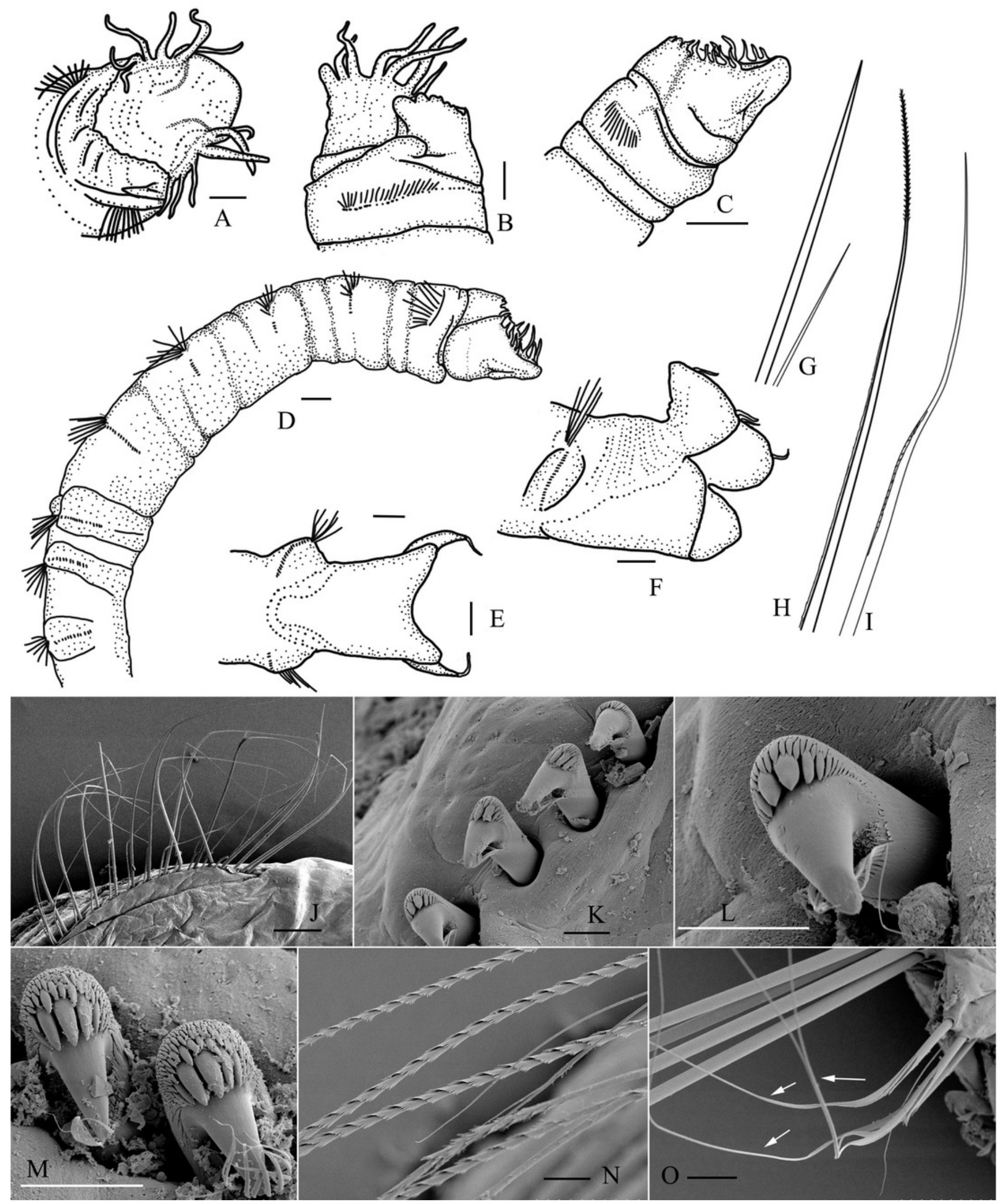